\title{
Can field distributions of marine predacious nematodes be explained by sediment constraints on their foraging success?
}

\author{
Fabiane Gallucci ${ }^{1,2}$, Maaike Steyaert ${ }^{1}$, Tom Moens ${ }^{1, *}$ \\ ${ }^{1}$ Marine Biology Section, Biology Department, Ghent University, Krijgslaan 281 (S8), 9000 Ghent, Belgium \\ ${ }^{2}$ Laboratório de Ciências Marinhas, Universidade do Sul de SantaCatarina, Av Colombo Sales 84, Laguna, SC, \\ 88790-000, Brazil
}

\begin{abstract}
Factors controlling field distributions of benthic infauna remain poorly understood. Enoploides longispiculosus is a prominent predacious nematode in sandy sediments of the North Sea and adjacent estuaries. This study assesses the distribution of E. longispiculosus and of prey nematodes in an intertidal flat (the Paulina) relative to variation in sediment characteristics. Predator densities varied strongly, even between sites with only subtle differences in sediment composition. E. longispiculosus abundances were positively correlated with grain size, proportion of fine sand and emersion period during low tides, and negatively with silt, very fine sand content and prey densities. We then tested whether and how grain size, silt content and water content affected predation rates and prey selectivity in E. longispiculosus using microcosm experiments with 2 prey species. Each of these sediment characteristics per se strongly affected predation efficiency but not selectivity. Increases in silt fraction and decreases in grain size and water content strongly reduced predation rate. These effects compared exceptionally well with the range of silt contents and grain sizes in which E. longispiculosus is abundant on the Paulina tidal flat, suggesting that its field distribution is governed at least in part by sedimentary effects on foraging efficiency. Sediment water content also impacted predation rates; however, its effect did not follow a pattern predicted by field data on emersion time. Hence, even small shifts in sediment composition may strongly affect the activity of predacious nematodes, and both temporal and small-scale spatial variability in sediment characteristics likely affects predator-prey dynamics on tidal flats.
\end{abstract}

KEY WORDS: Predation · Nematode communities $\cdot$ Top-down control $\cdot$ Intertidal flat $\cdot$ Sediment characteristics

\section{INTRODUCTION}

In coastal marine environments, predation is considered an important process that regulates spatial distribution and population dynamics of many animals in soft sediments (Ambrose 1984, Commito \& Ambrose 1985, Wilson 1990, Ólafsson et al. 1994, Thrush 1999). However, the factors controlling field distributions of predatory infauna, and thus potentially affecting their impact on prey populations, remain poorly understood.

In benthic ecology, there is a long history relating the distribution and abundance of organisms to sediment characteristics (Snelgrove \& Butman 1994). A strong feedback between sediment granulometry and the structure and functioning of the benthic food web has been observed (Herman et al. 2001). However, while large-scale distribution patterns of benthic fauna have often been related to variations in sediment properties, far less is known about the causes of these observed patterns and about how sediment properties affect the typically high smaller-scale patchiness of benthic organisms. Communities of nematodes, the predominant meiofaunal-sized metazoans in marine soft sediments, show both strong relations to sediment properties on larger (kilometre) scales and a pronounced patchiness on small (centimetre to metre) scales (Heip 
et al. 1985). Predacious nematodes, in particular, are often much more abundant and species-diverse in sediments with little or no silt than in silty ones (Warwick 1971, Tita et al. 2002, Steyaert et al. 2003), but the reasons for such trends are still uncertain.

Enoploides longispiculosus is a prominent predacious nematode in sandy sediments of the North Sea and adjacent estuaries, and its distribution appears to be strongly linked to sediment characteristics (Vincx et al. 1990, Li \& Vincx 1993, Soetaert et al. 1994, 1995, Steyaert et al. 2001, 2003). Recent laboratory experiments have shown that this predator feeds selectively on other nematodes (Moens et al. 1999, 2000) and ciliates (Hamels et al. 2001) at rates sufficient to influence prey biomass and species composition. However, these laboratory results are yet to be translated to field conditions, where a variety of sediment- and hydrodynamics-related factors may affect $E$. longispiculosus foraging success and hence its impact on prey communities and on microbial-meiofaunal foodwebs.

The present study addresses the question of whether field distributions of Enoploides longispiculosus can be explained by sediment constraints on its foraging success. The spatial distribution of E. longispiculosus over an intertidal flat with variable sediment composition and its relation to other nematode abundances ('potential prey') and sediment characteristics were investigated. Based on this field information, 3 sediment characteristics were identified as potential determinants of the abundance of E. longispiculosus: sediment (mean) grain size, silt content and water content as linked to emersion period during low tides (exposure time). We hypothesized that (1) the preference of $E$. longispiculosus for fine and medium sandy sediments could be explained by grain-size effects on predation efficiency,

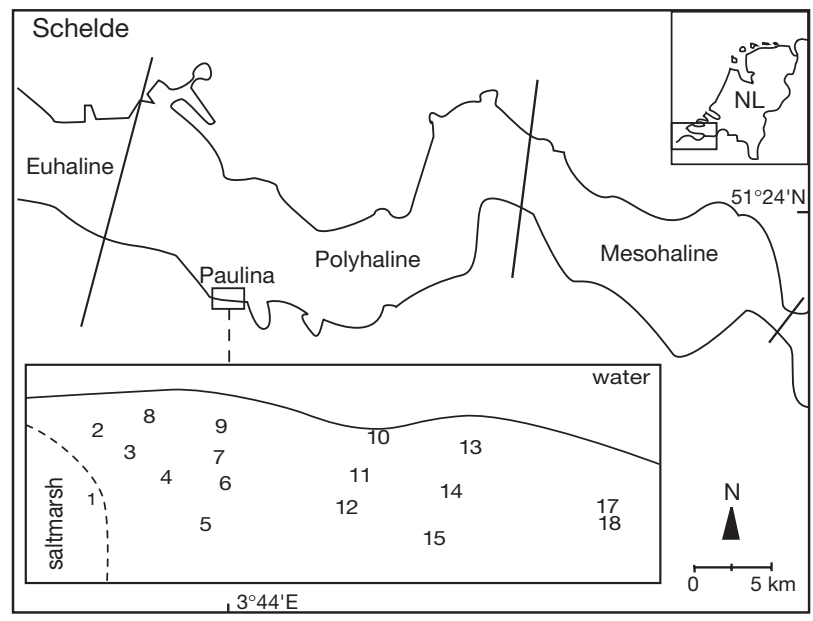

Fig. 1. Schelde estuary, SW Netherlands (NL), indicating the location of the Paulina intertidal flat and the approximate position of the sampling stations
(2) the presence/abundance of silt may further constrain the suitability of sediments for E. longispiculosus, and (3) published vertical migration behaviour of $E$. longispiculosus in intertidal sediments as a function of the tides (Steyaert et al. 2001) may reflect an impact of sediment water content on the predator's foraging efficiency. Since E. longispiculosus is a selective feeder (Moens et al. 2000, Hamels et al. 2001), we further hypothesized that prey preferences may be modified by the same 3 sediment characteristics. We therefore performed controlled laboratory experiments to assess the effects of each of these sediment characteristics separately on the foraging efficiency and prey selectivity of $E$. longispiculosus. The ecological implications of differential predation rates as a function of changes in sedimentology are discussed.

\section{MATERIALS AND METHODS}

Sampling and processing. The Paulina intertidal flat is a ca. $2 \mathrm{~km}^{2}$ tidal flat in the polyhaline reach of the Westerschelde Estuary, SW Netherlands (Fig. 1). It is characterized by substantial variability in sediment characteristics, from very fine sands with high silt content on the western side (where the tidal flat borders a salt marsh) to medium sands with virtually no silt on the eastern, most upstream side. Average tidal range is ca. $4.1 \mathrm{~m}$ and varies between $3.3 \mathrm{~m}$ at neap tide and 4.7 $\mathrm{m}$ at spring tide. During October-November 2001, 18 stations were sampled during low tide over the whole area of the tidal flat (Fig. 1).

Three replicate meiofauna samples were taken at each station with $3.6 \mathrm{~cm}$ inner diameter plexiglass corers down to a depth of $10 \mathrm{~cm}$. A preliminary sample screening showed that $>80 \%$ of Enoploides longispiculosus individuals were confined to the top $2 \mathrm{~cm}$ of the sediment, in agreement with previous findings elsewhere in this estuary (Steyaert et al. 2001). Therefore, only the top $2 \mathrm{~cm}$ were analysed for a description of the horizontal distribution of E. longispiculosus. Samples were fixed with a hot $\left(60^{\circ} \mathrm{C}\right) 4 \%$ formaldehyde solution. Fixed samples were sieved through a 38 $\mu \mathrm{m}$ sieve and extracted by centrifugation-flotation with Ludox HS40 (specific gravity of 1.15) (modified after De Jonge \& Bouwman 1977). All meiofaunal taxa were enumerated using a stereomicroscope after staining with Rose Bengal. Abundances of E. longispiculosus and other nematodes (which are all potential prey for E. longispiculosus) were counted separately.

Sediment granulometry and organic carbon content of the top $2 \mathrm{~cm}$ at each station were determined on 3 replicate samples per station. Sediment grain size was analysed on a Coulter LS 100 Particle Size Analyser, yielding results on the 4 to $850 \mu \mathrm{m}$ size fractions 
(larger-sized particles were virtually absent from all our sampling sites). Sediment fractions were defined according to the Wentworth scale (1992). Organic carbon content was determined after flash combustion on a CHN analyser, after 'in situ' acidification with dilute $\mathrm{HCl}$ (Nieuwenhuize et al. 1994).

Phytopigment concentrations were used as proxies for microphytobenthos biomass. Three replicate samples per station were taken with a plastic, cut-off syringe (diameter $=1.2 \mathrm{~cm}$ ). Pigments were extracted (again only from the upper $2 \mathrm{~cm}$ ) with $90 \%$ (volume/ volume) acetone at $4{ }^{\circ} \mathrm{C}$ in the dark and separated by reverse-phase high-performance liquid chromatography on a Gilson C-18 HPLC chain (modified after Mantoura \& Llewellyn 1983). Concentrations of the phytopigments chl $a$, chl $c$, fucoxanthin and lutein were then determined both spectrophotometrically and fluorometrically.

Experiments. Even though the environmental variables in our study were often not independent, the field data allowed identification of 3 variables as potential individual determinants of the abundance of Enoploides longispiculosus on the Paulina tidal flat: silt content, grain size and inundation time (which affects water content during low-tide exposure). Therefore, we designed experiments to test the effect of each of these factors separately on the predation efficiency and selectivity of E. longispiculosus.

Collection of Enoploides longispiculosus for experiments was done by bulk sampling of the upper 1 to 2 $\mathrm{cm}$ of sediment at 2 Paulina tidal flat stations where this nematode is always very abundant. Live nematodes were extracted by decantation over a $38 \mu \mathrm{m}$ sieve after vigorous shaking of the sediment with tap water. They were subsequently washed from the sieve with filtered water from the study site, and $E$. longispiculosus was hand-sorted directly to the experiments under a binocular microscope. Only active adult and/or 4th-stage juveniles were used in our experiments.

The monhysterid nematodes Diplolaimelloides meyli and Diplolaimelloides oschei were offered as prey in the experiments. Diplolaimelloides oschei is easily differentiated from $D$. meyli by its long and slender tail, and both prey species are readily distinguished from the predator. They were isolated from decaying Spartina leaves in the Paulina salt marsh and cultivated synxenically with bacteria from their habitat (Moens \& Vincx 1998). Nematodes were handpicked from such cultures with the tip of a fine needle and directly introduced to the experiments. It is important to note that neither prey species is typical of the sedimentary habitats frequented by Enoploides longispiculosus. Both species have, however, been shown to be suitable prey for E. longispiculosus in laboratory experiments (Moens et al. 1999, 2000, Hamels et al. 2001), the functional response of E. longispiculosus to these prey nematodes has been established (Moens et al. 2000), and there are obvious advantages to using prey from standardized cultures over non-culturable prey isolated from a variable environment (Moens \& Vincx 1998).

Effects of sediment grain size on predation rates and prey selectivity of Enoploides longispiculosus. In order to elucidate the influence of sediment grain size on the predation rate and on the prey selectivity of $E$. longispiculosus, 100 Diplolaimelloides meyli and 100 D. oschei were offered as prey to 10 predators in microcosms. The total prey densities in the present experiments roughly corresponded to 200 prey $10 \mathrm{~cm}^{-2}$ in a $2 \mathrm{~cm}$ sediment horizon, which is at the lower end of prey nematode densities on the Paulina tidal flat (see 'Results' section). However, functional responses of $E$. longispiculosus are most pronounced at still lower prey densities, and predator-prey encounters at this prey density are probably largely in excess of actual predation rates (Moens et al. 2000). Microcosms consisted of $3.5 \mathrm{~cm}$ diameter Petri dishes containing azoic sediment. Sediments were collected from different stations on the Paulina intertidal flat and different grain size fractions were obtained by sieving dried samples over a 'tower' of 355, 250, 212, 180, 150, 125 and $90 \mu \mathrm{m}$ mesh size sieves. This resulted in 6 treatments consisting of the following grain size fractions: 90-125, 125-150, 150-180, 180-212, 212-250 and 250-355 $\mu \mathrm{m}$. The respective mean grain sizes were 97, 136, 164, 198, 234 and $289 \mu \mathrm{m}$. Median grain sizes were always within $2 \mu \mathrm{m}$ of mean grain size, except for the smallest sediment fraction where median grain size was 114 $\mu \mathrm{m}$.

Each Petri dish contained $8 \mathrm{~g}$ of dry sediment, which was then water-saturated with $2.5 \mathrm{ml}$ of water from the study site. This habitat water was first filtered over a $0.8 \mu \mathrm{m}$ Millipore filter in order to remove all eukaryotic organisms. Microcosms were then kept in the dark for $24 \mathrm{~h}$ at $16^{\circ} \mathrm{C}$ prior to the start of the experiment. Two hundred prey nematodes (100 Diplolaimelloides meyli and $100 \mathrm{D}$. oschei) were added to each microcosm by manual transfer from monospecific prey cultures (see above). Ten Enoploides longispiculosus were then inoculated on each Petri dish. Microcosms were incubated at $16^{\circ} \mathrm{C}$ in the dark for $24 \mathrm{~h}$. There were 4 replicates for each treatment. Controls consisted of parallel microcosms with the same prey nematodes but without predators. Preliminary control tests in different sediment types (encompassing different mean grain sizes, water content and all silt content used in the experiment described below) revealed no significant treatment effects on either pooled or species-specific prey survival in the absence of predators. We therefore 
chose to include only 2 control treatments in the actual experiments, i.e. at the extremes of each tested range (largest and smallest grain size fraction, highest and lowest silt content, and highest and lowest water content). Preliminary incubations of predators without prey showed an almost $100 \%$ survival of E. longispiculosus under our experimental conditions, and indeed we consistently recovered all predators from all the experimental treatments reported here. In the absence of prey, however, the predators displayed hardly any activity and remained at or near the inoculation spot.

After $24 \mathrm{~h}$ of incubation, sediments were collected from the microcosms and fixed in $4 \%$ formaldehyde solution. These samples were sieved through a $32 \mu \mathrm{m}$ sieve and nematodes elutriated by centrifugationflotation with Ludox (see above). Samples were stained with Rose Bengal and predator and prey species counted under a stereomicroscope.

Effects of sediment silt content on predation rates and prey selectivity of Enoploides longispiculosus. The same experimental design used for assessing grain-size effects was adopted to test the effects of different silt contents on predation rate and prey selectivity of E. longispiculosus. Sediments devoid of silt and composed mainly of medium and fine sand (46 and $53 \%$ respectively) were obtained from the Paulina tidal flat. Silt (here defined as the sediment fraction $<63 \mu \mathrm{m}$ ) was obtained by filtering muddy sediment from a Paulina tidal flat station at the edges of the salt marsh over a $63 \mu \mathrm{m}$ mesh. Both silt and sand fractions were combusted at $550^{\circ} \mathrm{C}$ for $4 \mathrm{~h}$ to remove organic matter, so that any effects could be unequivocally attributed to physical properties of the sediment fractions rather than to other, associated variables. Four treatments with different silt content were applied: 0, 6,12 and $24 \%$ of sediment dry wt. Incubation conditions, replication, controls and sample processing were as in the previous experiment.

Effects of sediment water content on predation rates and prey selectivity of Enoploides longispiculosus. To verify the influence of sediment water content on the predation rate and prey selectivity of E. longispiculosus, microcosms with different water contents were established by adding variable amounts of habitat water (filtered over a $0.8 \mu \mathrm{m}$ Millipore filter) to Petri dishes containing azoic sediment $(46 \%$ medium and $53 \%$ fine sand). Prior to this experiment, surface sediment (upper $2 \mathrm{~cm}$ ) from one station of the tidal flat where Enoploides is consistently abundant was sampled in a 'dry' situation, i.e. after $>6 \mathrm{~h}$ of exposure on a sunny day. The water content (expressed as \% of sediment wet wt, estimated from weight loss after drying to constant weight) of this sediment (15\% wet wt) was applied as the 'dry' treatment. A 'wet' treatment consisted of water-saturated sediment $(34 \%$ wet wt water), and 2 intermediate situations (21 and $28 \%$ wet wt water) were also tested. Incubation conditions, replication, controls and sample processing were as in the previous experiments.

Data analyses. Field environmental data (sediment characteristics and phytopigments) were analysed using a correlation-based principal component analysis (PCA). To establish relations between Enoploides longispiculosus densities, the environmental variables and total densities of other nematodes (potential prey), a Spearman rank correlation analysis was applied.

For the experiments, prey consumption was calculated as the difference between the mean prey numbers remaining in the controls (consistently $>90 \%$ of added prey) and in the experimental incubations. To test for differences in the numbers of missing prey between treatments and prey species, and to check whether prey selectivity was dependent on treatment, a 2-way ANOVA was applied with species and treatments as fixed factors. No data transformation was necessary to meet the assumptions of normality (Kolmogorov-Smirnov test) and homogeneity of variances (Cochran's C-test) (Sokal \& Rohlf 1997). A Tukey HSD a posteriori test was applied for pairwise comparisons when significant differences were detected with ANOVA.

\section{RESULTS}

\section{Field distribution of meiofauna and Enoploides longispiculosus}

Nematodes dominated the meiofauna at all stations with mean densities ranging from 27 to 2431 ind. 10 $\mathrm{cm}^{-2}$. The predacious Enoploides longispiculosus was present at 16 of the 18 stations sampled (Fig. 2), with maximum densities of up to 236 ind $10 \mathrm{~cm}^{-2}$ and a maximum relative abundance of $25 \%$ of total nematode densities. Total densities of other nematodes ('potential prey') generally exhibited lower densities at those stations where Enoploides was most abundant (Fig. 2). Indeed, Spearman rank correlation analysis showed a negative correlation between densities of $E$. longispiculosus and other nematodes ('potential prey') $(\mathrm{R}=-0.76, \mathrm{p}<0.001)$.

\section{Environmental variables}

Mean grain size increased from downstream (very fine sand with high silt content, Stns 1 and 2) to upstream, where most of the stations were characterized by medium and fine sand with low or virtually no silt content. However, substantial variability in mean 

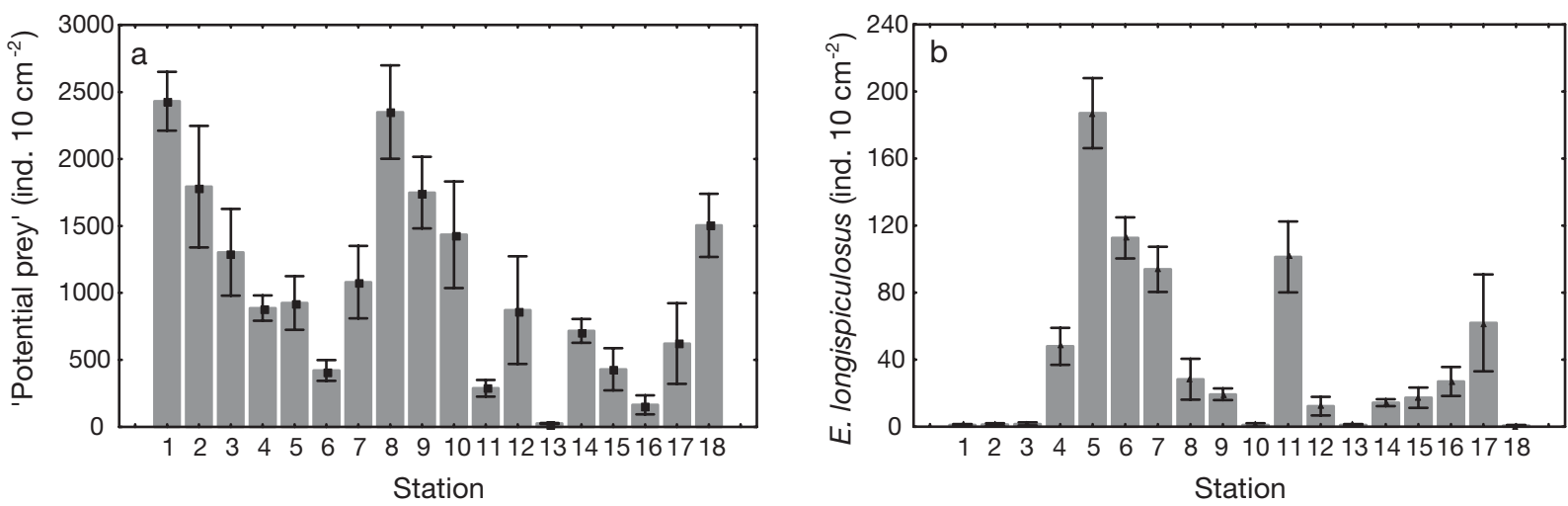

Fig. 2. Densities of (a) 'potential prey' (all nematodes other than Enoploides longispiculosus) and (b) E. longispiculosus at the Paulina intertidal flat. Data are means \pm 1 SE of 3 replicates. Position of stations is depicted in Fig. 1

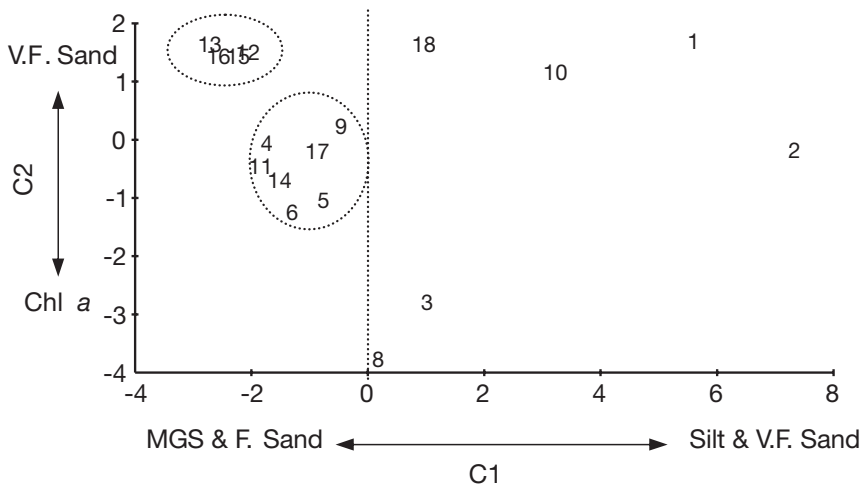

Fig. 3. Ordination of station sediment characteristics and phytopigment concentrations by a correlation-based principal component analysis. MGS: mean grain size; F. Sand: fine sand $(125$ to $250 \mu \mathrm{m})$; V.F. Sand: very fine sand (63 to $125 \mu \mathrm{m})$. Stn 7 was omitted from the ordination analysis because phytopigment data were missing

grain size and in sediment composition was observed among intermediate sites (esp. Sites 3 to 10). Organic carbon content correlated positively with very fine sand and silt percentages. Chl a concentrations varied strongly, from 2.7 to $55 \mathrm{\mu g} \mathrm{g}^{-1}$ sediment dry wt.

In a correlation-based PCA on all environmental data, components 1 and 2 explained $83.7 \%$ of the variability (PC1-63.8\%; PC2-19.9\%, Fig. 3). On the first component, stations with higher silt content were clearly separated from stations with higher mean grain size. High positive values were associated with silt (4 to $63 \mu \mathrm{m}$ ), very fine sand (63 to $125 \mu \mathrm{m}$ ) and high sediment organic carbon content, while high negative values were due to lower mean grain sizes and higher fine sand (125 to $250 \mu \mathrm{m}$ ) percentages. Stations separated by higher mean grain size in the PC1 clustered in 2 groups along the second ordination axis, the upper being characterized mainly by higher very fine sand percentages and the lower by higher chl a concentrations. Comparing the distribution of stations on the
PCA analysis with their location in the field (Fig. 1), there is no clear gradient in sediment composition along the Paulina tidal flat but rather a mosaic of stations with substantial variability in sediment characteristics.

\section{Relationships between environmental variables and Enoploides longispiculosus}

Superimposition of the densities of Enoploides longispiculosus at each station (Fig. 4b) onto the PCA plot of the environmental variables (Fig. 4a) indicates that its distribution is highly correlated to the environmental variables responsible for the differentiation of the groups of stations in the PCA. Superimposing the values of mean grain size (Fig. 4c) and the percentages of fine sand (Fig. 4d) shows a clear positive correlation of E. longispiculosus with these variables. Indeed, among the stations with higher mean grain size (Fig. 4a, left), those which clustered on the basis of low very fine sand content (lower left) have the highest densities of $E$. longispiculosus. Finally, not only is E. longispiculosus absent from sediments with high (12 to $24 \%$ ) silt content, its abundance is also typically low at low silt content (6\%) (Fig. 4f). Spearman rank correlation analyses largely confirmed the above results: E. longispiculosus densities were positively correlated with mean grain size and with fine sand content and negatively correlated with very fine sand and silt content (all $\mathrm{p}<0.05$ ).

\section{Experiments}

Effects of sediment grain size on predation rates and prey selectivity of Enoploides longispiculosus

Prey consumption by Enoploides longispiculosus over a $24 \mathrm{~h}$ incubation differed between sediments with 

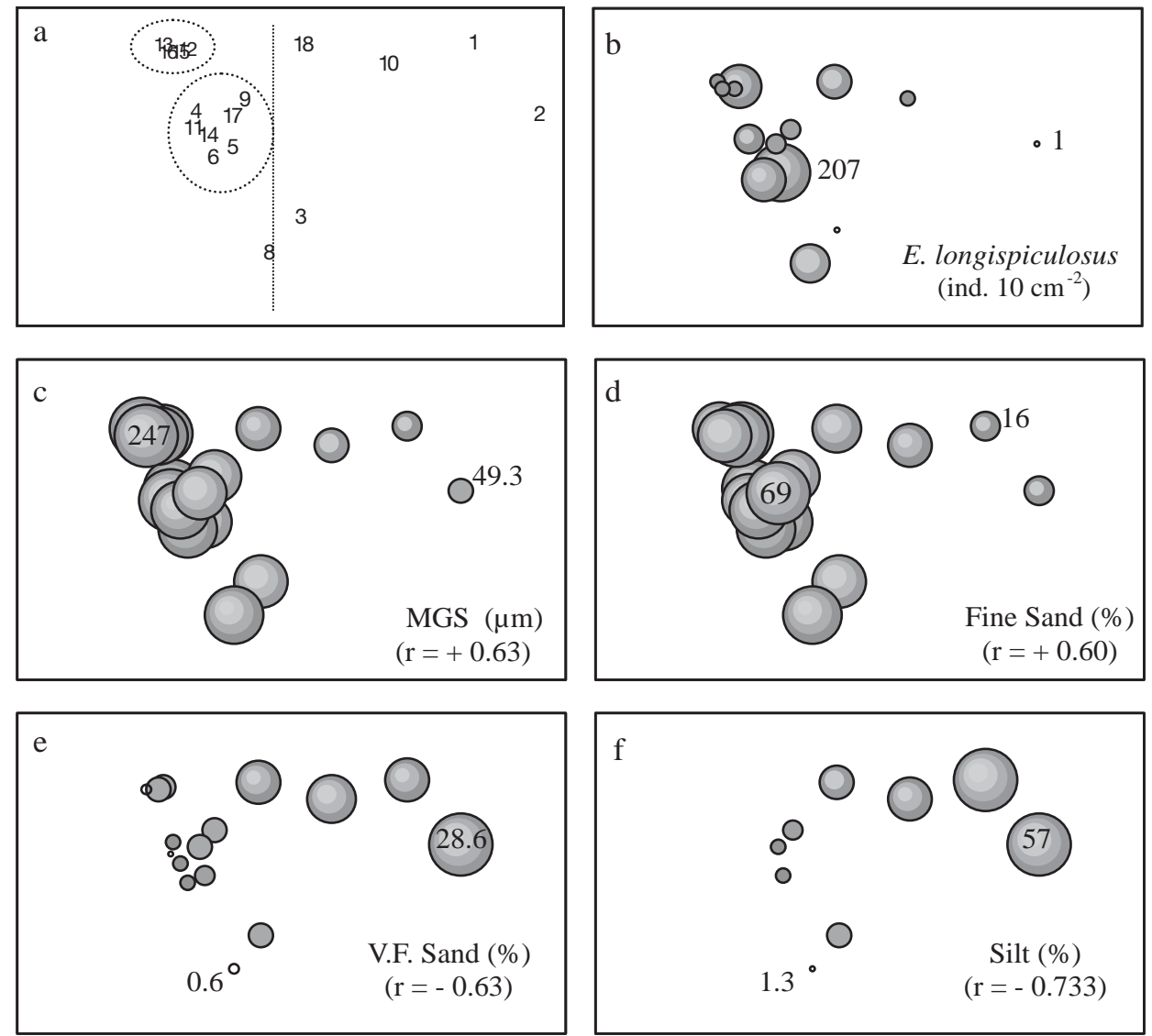

Fig. 4. Superimposition of Enoploides longispiculosus densities on PCA plot of sediment characteristics. (a) PCA plot as in Fig. 3; (b) E. longispiculosus densities; (c) mean grain size values (MGS); (d) fine sand percentages; (e) very fine sand percentages; (f) silt percentages. Data plotted on the graphs are minimum and maximum values of (b) nematode densities (ind. $10 \mathrm{~cm}^{-2}$ ), (c) mean grain sizes $(\mu \mathrm{m})$, (d) proportion (\%) of fine sand (125 to $250 \mu \mathrm{m})$, (e) proportion of very fine sand (63 to $125 \mu \mathrm{m})$ and (f) proportion of silt $(<63 \mu \mathrm{m})$. $\mathrm{r}$ indicates the Spearman rank correlation coefficient between each variable and E. longispiculosus density (c-f).

All $\mathrm{r}$ values are significant at $\mathrm{p}<0.01$
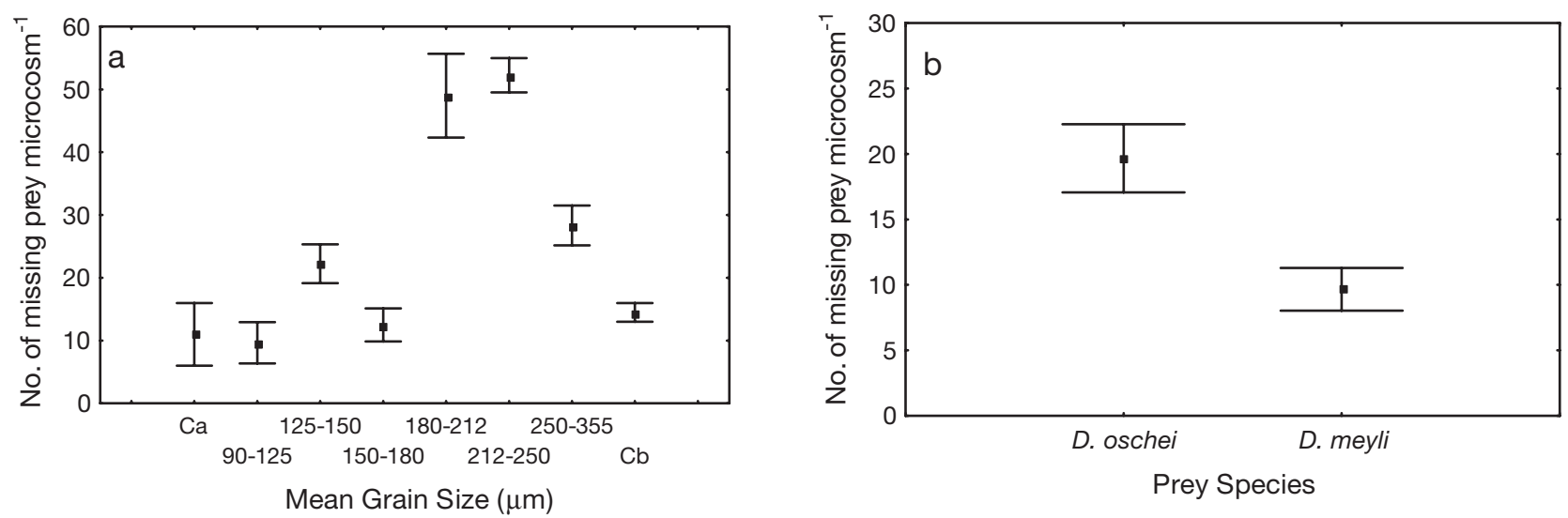

Fig. 5. Numbers of missing prey per microcosm after $24 \mathrm{~h}$ of incubation with 10 Enoploides longispiculosus in sediments of different grain sizes. Ca: control treatment at grain size fraction of 90 to $125 \mu \mathrm{m}$; Cb: control treatment at grain size fraction of 250 to $355 \mu \mathrm{m}$. Data of (a) both prey species combined and (b) the 2 prey species separately are shown, with all grain size treatments (except controls) averaged per species. Data are means \pm 1 SE of 4 replicates 
Table 1. Two-way ANOVA of differences in the numbers of missing prey per microcosm between Sediment, Prey species and Sediment $\times$ Species. Treatments were different grain size fractions (in $\mu \mathrm{m})$, silt content and water content (both in weight \%). Controls were (1) Ca: 90 to $125 \mu \mathrm{m}$ and Cb: 250 to $355 \mu \mathrm{m}$, (2) Ca: no silt and Cb: $24 \%$ silt, and (3) Ca: $15 \%$ water and Cb: $34 \%$ water for the grain size, silt content and water content experiments, respectively. Results of pairwise comparisons with Tukey's HSD test are given at $\mathrm{p}<0.05$. For the grain size treatments (HSD column), value followed by a hyphen indicates the grain size fraction with that value as its lower limit.Treatments that are jointly underlined did not differ significantly

\begin{tabular}{|c|c|c|c|c|c|c|c|c|c|}
\hline & \multicolumn{3}{|c|}{ Sediment } & \multicolumn{3}{|c|}{ Prey species } & \multicolumn{3}{|c|}{ Sediment $\times$ Prey Species } \\
\hline & $F$ & $\mathrm{p}$ & HSD & $F$ & $\mathrm{p}$ & HSD & $F$ & $\mathrm{p}$ & HSD \\
\hline Grain size $(\mu \mathrm{m})$ & 26.99 & $<0.001$ & $\frac{180-,}{150-,} \frac{212-}{250-,}>\frac{90-, 125-,}{\mathrm{Ca}, \frac{\mathrm{Cb}}{1}}$ & 48.44 & $<0.001$ & D.oschei > D.meyli & 1.86 & 0.116 & - \\
\hline Silt content (\%) & 10.75 & $<0.001$ & $\underline{0,} \underline{6}>\underline{12}, 24, \mathrm{Ca}, \mathrm{Cb}$ & 38.03 & $<0.001$ & D.oschei > D.meyli & 2.05 & 0.113 & - \\
\hline Water content (\%) & 17.27 & $<0.001$ & $28=(34>15,21, \mathrm{Ca}, \mathrm{Cb})$ & 12.07 & 0.002 & D.oschei > D.meyli & 1.51 & 0.224 & - \\
\hline
\end{tabular}
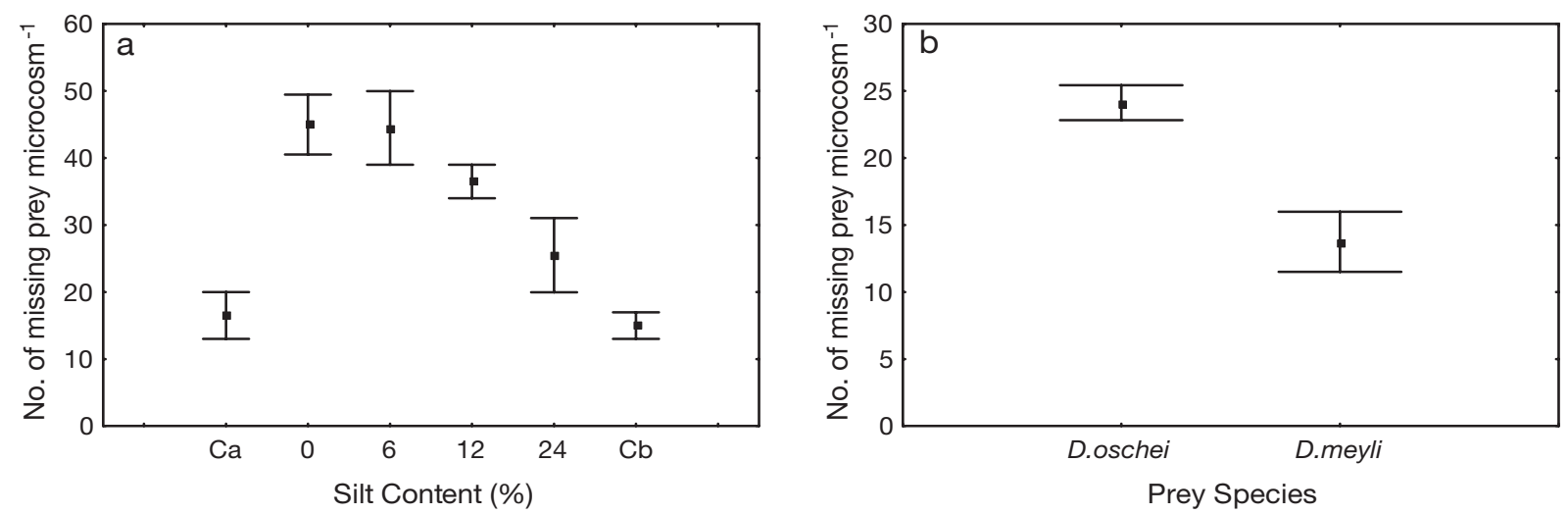

Fig. 6. Numbers of missing prey per microcosm after $24 \mathrm{~h}$ of incubation with 10 Enoploides longispiculosus in sediments of different silt content. Ca: control treatment without silt; $\mathrm{Cb}$ : control treatment with $24 \%$ silt. Data of (a) both prey species combined and (b) the 2 prey species separately are shown with all silt treatments (except controls) averaged per species. Data are means $\pm 1 \mathrm{SE}$ of 4 replicates

different grain size and between prey species (Fig. 5, Table 1). Predation was highest in sediments with grain size of 180 to $250 \mu \mathrm{m}$ (Fig. 5a, Table 1). Predation rate was significantly lower in sediments with both higher $(>250 \mu \mathrm{m})$ or lower $(<180 \mu \mathrm{m})$ grain size. Treatments with sediment grain size lower than $180 \mu \mathrm{m}$ did not differ significantly from the control (Table 1). E. longispiculosus consumed on average 3.7 prey per predator per $24 \mathrm{~h}$ when considering only the treatments covering a grain size range of 180 to $250 \mu \mathrm{m}$.

Diplolaimelloides oschei was preferentially preyed upon by E. longispiculosus, and no interaction was found for the combined effect 'grain size' $\times$ 'species' (Fig. 5b, Table 1). The number of prey missing in the controls did not differ between $D$. meyli and $D$. oschei nor between both control treatments (both $\mathrm{p}>0.05$ ).

Effects of sediment silt content on predation rates and prey selectivity of Enoploides longispiculosus

Prey consumption (calculated as the difference between prey numbers remaining in the control and in the experimental incubations) was significantly higher in sediments without silt or with low silt content; the treatment with the highest silt content did not differ significantly from controls (Fig. 6a, Table 1). Prey consumption averaged 3 prey per predator per day $(24 \mathrm{~h})$ over the treatments with 0 to $12 \%$ silt.

Significantly more Diplolaimelloides oschei than $D$. meyli were eaten by Enoploides longispiculosus (Fig. $6 b$, Table 1). Two-way ANOVA (Table 1) showed no interaction between sediment and species, illustrating that this preferential predation on $D$. oschei was independent of silt content. The controls showed that the efficiency of isolation and counting was identical for $D$. oschei and D. meyli and was unaffected by silt content (both $\mathrm{p}>0.05$ ).

Effects of sediment water content on predation rates and prey selectivity of Enoploides longispiculosus

Prey removal was significantly higher in sediments with higher water content (28 and $34 \%$ ) than in the drier sediments (15 and $21 \%$ water content), the latter 

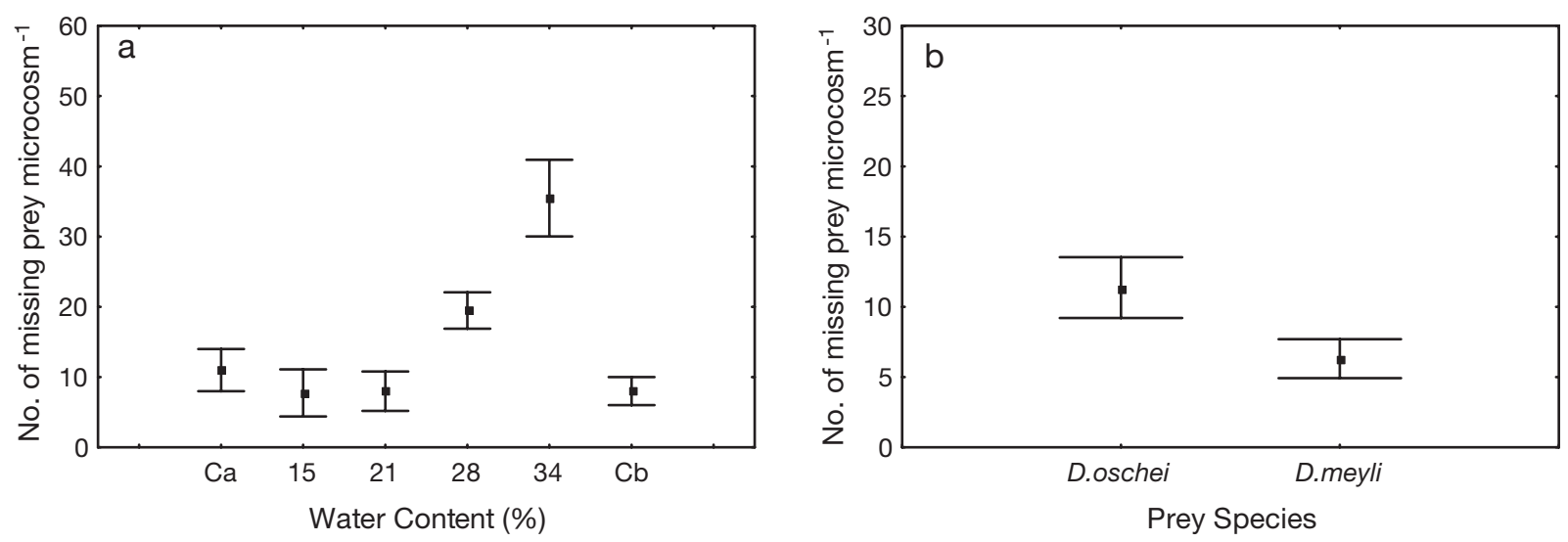

Fig. 7. Numbers of missing prey per microcosm after $24 \mathrm{~h}$ of incubation with 10 Enoploides longispiculosus in sediments of different water content. Ca: control treatment with a water content of $21 \%$; $\mathrm{Cb}$ : control treatment with a water content of $34 \%$. Data of (a) both prey species combined and (b) the 2 prey species separately are shown, with all water content treatments (except controls) averaged per species. Data are means $\pm 1 \mathrm{SE}$ of 4 replicates

not differing significantly from controls (Fig. 7a, Table 1). Prey consumption averaged 3.5 prey per predator per day when only the 2 treatments with the highest water content are considered.

As in the previous 2 experiments, Enoploides longispiculosus caught significantly more Diplolaimelloides oschei than D. meyli (Fig. 7b, Table 1). Two-way ANOVA (Table 1) showed no interaction between sediment water content and species; numbers of $D$. oschei and $D$. meyli in controls did not differ, nor did their pooled numbers in controls of different water content (both $\mathrm{p}>0.05$ ).

\section{DISCUSSION}

Many studies have correlated infaunal invertebrate distributions with sediment grain size in aquatic environments, leading to the generalization of distinct associations between animals and specific sediment types (see review by Snelgrove \& Butman 1994). However, correlations do not identify the causes for the observed patterns (Underwood et al. 2000), and the mechanistic basis for this sort of sediment preference remains poorly understood. Sediment grain size covaries with sediment organic matter content, porewater chemistry, and microbial abundance and composition, all of which could directly or indirectly influence infaunal distributions (Snelgrove \& Butman 1994, Thrush et al. 2003), and there is little evidence that the sediment matrix per se is a major determinant of infaunal species distribution. This particularly holds for nematodes, the predominant meiofaunal taxon (Heip et al. 1985). However, our experiments demonstrate that even small changes in specific characteristics of the sediment matrix have important implications for the foraging efficiency of Enoploides longispiculosus. The good correspondence between these experimental results and the distribution of this predacious nematode on the Paulina tidal flat further supports our hypothesis that the preference of E. longispiculosus for fine and medium sandy sediments may be explained by sediment effects on this nematode's predation efficiency.

The sediment preferences found for E. longispiculosus on the Paulina tidal flat are in line with previous reports that Enoplidae tend to increase in abundance with increasing grain size and decreasing silt-clay content (Heip et al. 1985). In addition, a lower grain size limit of $200 \mu \mathrm{m}$ was found for Enoploides harpax (Wieser 1959). Likewise, E. longispiculosus and other members of this genus are abundant in medium to fine sandy sediments of the North Sea (Vincx et al. 1990), the Schelde and other European estuaries (Platt \& Warwick 1983, Soetaert et al. 1994, 1995, Steyaert et al. 2001, 2003) and have distributions that appear strongly linked to sediment characteristics.

At the Paulina tidal flat, apart from 3 'muddy' (silt content $>30 \%$ ) stations, mean grain size showed only a relatively small variability (from 180 to $250 \mu \mathrm{m}$ ). Nevertheless, even when these muddy stations were omitted from the analysis, Enoploides longispiculosus densities were positively correlated with mean grain size as well as with the fraction of fine sand. Although correlation does not necessarily imply causation, our experiments clearly demonstrate that slight changes in sediment grain size per se can affect the predation efficiency of E. longispiculosus. In contrast to suggestions of a progressive increase in abundance of Enoploides and other predacious nematodes with increasing mean grain size (Heip et al. 1985), our experiments suggest a strong specialization of E. longispiculosus to a narrow 
range of grain sizes (from 180 to $250 \mu \mathrm{m}$ ). In grain-size classes over $250 \mu \mathrm{m}$ and below $180 \mu \mathrm{m}$, predation was strongly reduced or even totally impeded (none of these grain size fractions yielded prey numbers that differed significantly from the controls). This is in agreement with the field distribution of E. longispiculosus at the Paulina site: Enoploides densities correlated positively with the fine sand fraction (125 to 250 $\mu \mathrm{m})$ but negatively with the percentage of very fine sand (63 to $125 \mu \mathrm{m}$ ) and showed no correlation with the medium sand fraction (250 to $500 \mu \mathrm{m})$. Active carnivores and omnivores live as epifauna or in the semifluid sediment surface where they behave as interstitial forms (Jumars \& Fauchald 1977, Schwinghamer 1981, Tita et al. 1999). Wieser (1959) argued that sediments with a median particle diameter of approx. 200 $\mu \mathrm{m}$ constitute a barrier separating the bulk of interstitial organisms from burrowing animals. This may explain why E. longispiculosus, a fairly large surface or subsurface dweller, is incapable of catching prey in sediments with low $(<180 \mu \mathrm{m})$ grain size, but not why predation efficiency was significantly reduced in sediments with grain size larger than $250 \mu \mathrm{m}$. Here, interstitial spaces begin to fill up with fine material. However, we excluded fine materials from our experiment. It has been suggested that nematodes from coarser sediments have morphological adaptations to life in large interstices, such as stout and annulated bodies (Willems et al. 1982, Soetaert et al. 2002), which do not apply to E. longispiculosus, but the functional implications of such morphological adaptations remain insufficiently understood.

(Mean) grain size, however, is not the only key sedimentary factor affecting spatial patterns in Enoploides longispiculosus abundance. On the Molenplaat, for instance, another tidal flat in the Schelde estuary, E. longispiculosus comprises $40 \%$ (density-wise; in biomass terms their dominance is considerably higher) of total nematodes at a station characterized by fine sandy sediments (median grain size $172 \mu \mathrm{m}$ ) with virtually no silt $(<5 \%)$ (Steyaert et al. 2001). Approximately $200 \mathrm{~m}$ south on the same tidal flat, lower bottom shear results in slightly elevated silt levels (ca. 13\%) on otherwise very similar fine sands (median grain size $163 \mu \mathrm{m})$ (Herman et al. 2001). Here, E. longispiculosus densities drop dramatically (Moens \& Steyaert unpubl. data), suggesting an important effect of silt and very fine sand content on its distribution.

Both the field data from the Paulina tidal flat and our experiments confirm our hypothesis that silt may further constrain the suitability of sediments for Enoploides longispiculosus. The experiment with different silt fractions showed a decrease in predation rates of Enoploides by as much as $30 \%$ for a relatively small increase in silt content (from 0 to $12 \%$ silt). $E$. longispiculosus was even incapable of catching prey in sediments containing $>12 \%$ silt. These experimental results compare remarkably well with the field distribution of E. longispiculosus on the Paulina tidal flat (this study) and on the Molenplaat (Steyaert et al. 2001). On the Paulina tidal flat, even slight increments in silt or very fine sand content coincided with (much) lower abundances of Enoploides: it was most abundant in sandy sediments containing less than $6 \%$ silt but rare or absent in sediments with $12 \%$ silt or more. The proportion of silt determines the degree of sediment pore space filling, and thus the upper size limits of interstitial species (Schwinghamer 1981). It will therefore likely impact large, motile predators such as $E$. longispiculosus which need to actively catch their prey. However, the exact mechanisms behind the observed silt content effect on predation rates in $E$. longispiculosus remain to be elucidated.

Steyaert et al. (2001) report a downward migration of Enoploides longispiculosus during low-tide exposure followed by a return to the more superficial layers during submersion. This is at variance with the idea that meiofauna move down when tidal flats are submerged to avoid being eroded (Boaden \& Platt 1971, Palmer 1986, Fegley 1987). Our experiments offer a plausible explanation for this behaviour. Porewater drainage during low tide on the Paulina tidal flat often temporarily results in water content in the range of those impeding predation by Enoploides in our experiments (15 to $21 \%$ wet wt). Downward migration during low tide will therefore alleviate effects of reduced water content on predation efficiency. Observations during our experiments showed that while in wetter sediments Enoploides behaved like a surface dweller, it immediately moved down into the sediment when in drier microcosms. On the Paulina tidal flat, however, an overall positive correlation between E. longispiculosus densities and low-tide exposure time was found, suggesting that the sedimentary constraints (grain size, \% silt) per se are more important in determining the field distribution of this predator than water content, in line with an early study by Wieser (1959).

Nevertheless, the observed effects of water content on predation by Enoploides longispiculosus likely have important consequences for this predator's overall fitness. Based on data on respiration, assimilation efficiency and prey and predator biomass (Moens et al. 1999), one can calculate that the consumption of just 1 extra prey individual per day would substantially raise production rates (by as much as $60 \%$ ) and production efficiency. Hence, even short episodes of 'inactivity' or reduced efficiency, caused by porewater drainage at low tide, may impact this predator's in situ success. Moreover, the vertical migration by Enoploides longispiculosus as a function of the tides is opposite to 
that of several of its most abundant candidate prey species (Steyaert et al. 2001), which may further affect its predation success.

Enoploides longispiculosus showed a clear preference for Diplolaimelloides oschei over its congener $D$. meyli, which may be either a consequence of different prey escape mechanisms or of a true feeding preference. Despite strong effects of sediment properties on predation rates, they did not affect this feeding selectivity, thus refuting our hypothesis that prey preference may be subject to sediment constraints. However, both prey species used here are typical of phytodetrital deposits and underlying muddy sediments in salt marshes, and the sandier microcosm environments in our study likely affected their motility. Our observations show that E. longispiculosus was probably considerably more motile in our microcosms than the prey species used here (T. Moens pers. obs.). As a result, encounter probabilities between predator and prey largely depend on the predator's own motility (Moens et al. 2000). Thus, the observed sediment effects on predation rates likely result from changes in the behaviour of the predator rather than of its prey. In predator-prey combinations where the prey is more motile and equally affected by changes in sediment properties, both predation rate and prey selectivity may be constrained by sediment characteristics.

Notwithstanding differences in experimental set-up, all lab experiments conducted thus far with Enoploides longispiculosus and monhysterid nematode prey (Moens et al. 1999, 2000, Hamels et al. 2001, this study) have yielded very similar predation rates (between 2.5 and 5 prey predator ${ }^{-1} \mathrm{~d}^{-1}$ ), suggesting that these rates may be representative and that the conclusions about a significant top-down impact on prey nematode and ciliate communities (Moens et al. 2000, Hamels et al. 2001), even at moderate to low predator density, are relevant to field situations. This is corroborated by the distribution of E. longispiculosus and of other nematodes (potential prey) on the Paulina intertidal flat: other nematode densities correlated negatively with $E$. longispiculosus abundance, even when the muddy stations (1, 2 and 10) where Enoploides was absent or rare were omitted from the analysis. It also supports the idea that the remarkable vertical distribution pattern of prey nematodes at the Molenplaat, with highest densities below a depth of $2 \mathrm{~cm}$ ( $E$. longispiculosus is restricted to these upper $2 \mathrm{~cm}$ ), is a result of top-down control in the upper sediment stratum (Steyaert et al. 2001).

Temporal changes in sediment properties may have implications for the temporal dynamics of prey nematode communities. Siltation/desiltation cycles as commonly observed on tidal flats in the Schelde estuary (Herman et al. 2001) could affect the top-down effect of
Enoploides longispiculosus by seasonally reducing its predation efficiency. In the same way, but over the time scale of a tidal cycle, water content of the sediment will affect predation efficiency and may provide prey with temporary refuges. Steyaert et al. (2001) described an upward movement of the diatom-feeding Daptonema setosum during low tide, followed by a downward migration during submersion. Diatom production and biomass build-up at the sediment surface are high during tidal exposure (Guarini et al. 1997) and may thus offer high food availability to grazers. At the same time, by making an inverse vertical migration relative to the predator E. longispiculosus, D. setosum may effectively reduce predation pressure. Furthermore, variability in sediment relief on a scale of metres implies that while many stations are subject to rapid porewater drainage, some patches within those stations can remain (almost) water-saturated over most of the tidal cycle. This patchiness at a small spatial scale may also provide prey with temporary refuges where they can be active and experience a lesser predation pressure.

Efforts to understand interactions between higher trophic-level organisms and their resources usually focus on habitat selection. If resource exploitation is the primary function of habitat selection, then the spatial distribution of a predator should follow the spatial pattern of its prey (Morris 1987). On the other hand, if constraints prohibit accurate resource assessment and/or utilization, then the distribution of predators may or may not reflect that of their prey (Russel et al. 1992). Our results strongly suggest that field distributions of predacious nematodes may be governed by sedimentary effects on their foraging efficiency, rather than by food availability per se. The present study undoubtedly bears relevance beyond the case study presented here because predacious nematodes are ubiquitous and often abundant in a variety of aquatic sediments and terrestrial soils. Moreover, predatory nematodes in general tend to be more abundant and speciose in sandy sediments compared to very fine, silt-rich sediments (Heip et al. 1985), suggesting that constraints on foraging success imposed by sediment characteristics, as observed here for E. longispiculosus, may equally occur in other predacious meiobenthic species.

Predatory nematodes may not only impact prey nematode communities but also ciliates (Hamels et al. 2001), other metazoan meiobenthos (Moens \& Vincx 1997) and perhaps macrobenthos through predation on settling larvae (Watzin 1983, 1985). If even minor changes in grain size or silt/very fine sand content can dramatically affect benthic key species such as this predacious nematode, anthropogenic changes in sediment composition such as the deposition of dredged 
material on tidal flats, a common practice in many European estuaries, may not only influence the composition of colonizing assemblages (Schratzberger et al. 2004) but is likely to have major impacts on ecosystem functioning.

Acknowledgements. Financial support for this research was obtained from the Flemish Fund for Scientific Research (Project 31521704) and from Ghent University (BOF Project 1205398). We are grateful to W. De Backer, M. Francis and B. Timmerman for help in field sampling and sample processing, to G. Fonseca for his help (and patience) with sorting nematodes for the experiments, and to G. Fonseca, S. Netto and 3 anonymous reviewers for stimulating comments on earlier drafts of this manuscript. D. Van Gansbeke and D. Schram assisted with the HPLC and sediment granulometric analyses, and J. Doekes from RIKZ (The Netherlands) kindly provided data on tidal range.

\section{LITERATURE CITED}

Ambrose WG Jr (1984) Role of predatory infauna in structuring marine soft-bottom communities. Mar Ecol Prog Ser 17:109-115

Boaden PJS, Platt HM (1971) Daily migration patterns in an intertidal meiobenthic community. Thallassia Jugosl 7 : $1-12$

Commito JA, Ambrose WG Jr (1985) Multiple trophic levels in soft-bottom communities. Mar Ecol Prog Ser 26:289-293

De Jonge VN, Bouwman LA (1977) A simple density separation technique for quantitative isolation of meiobenthos using the colloidal silica Ludox-TM. Mar Biol 42:143-148

Fegley SR (1987) Experimental variation of near-bottom current speeds and its effects on depth distribution of sand-living meiofauna. Mar Biol 95:183-191

Guarini JM, Blanchard GF, Gros P, Harrison SJ (1997) Modelling the mud surface temperature on intertidal flats to investigate the spatio-temporal dynamics of the benthic microalgal photosynthetic capacity. Mar Ecol Prog Ser 153:25-36

Hamels I, Moens T, Muylaert K, Vyverman W (2001) Trophic interactions between ciliates and nematodes from an intertidal flat. Aquat Microb Ecol 26:61-72

Heip C, Vincx M, Vranken G (1985) The ecology of marine nematodes. Oceanogr Mar Biol Annu Rev 23:399-489

Herman PMJ, Middelburg JJ, Heip C (2001) Benthic community structure and sediment processes on an intertidal flat: results from the ECOFLAT project. Cont Shelf Res 21: 2055-2071

Jumars PA, Fauchald K (1977) Between-community contrasts in successful polychaete feeding strategies. In: Coull BC (ed) Ecology of marine benthos. University of South Carolina Press, Columbia, SC, p 1-20

Li J, Vincx M (1993) The temporal variation of intertidal nematodes in the Westerschelde. I. The importance of an estuarine gradient. Neth J Aquat Ecol 27:319-326

Mantoura RFC, Llewellyn CA (1983) The rapid determination of algal chlorophyll and carotenoid pigments and their breakdown products in natural waters by reverse-phasehigh-performance liquid chromatography. Anal Chim Acta 151:297-314

Moens T, Vincx M (1997) Observations on the feeding ecology of estuarine nematodes. J Mar Biol Assoc UK 77: 211-217
Moens T, Vincx M (1998) On the cultivation of free-living marine and estuarine nematodes. Helgol Meeresunters 52:115-139

Moens T, Verbeeck L, Vincx M (1999) Feeding biology of a predatory and a facultatively predatory nematode (Enoploides longispiculosus and Adoncholaimus fuscus). Mar Biol 134:585-593

Moens T, Herman P, Verbeeck L, Steyaert M, Vincx M (2000) Predation rates and prey selectivity in two predacious estuarine nematode species. Mar Ecol Prog Ser 205: 185-193

Morris DW (1987) Ecological scale and habitat use. Ecology 68:362-369

Nieuwenhuize J, Maas YEM, Middelburg JJ (1994) Rapid analysis of organic carbon and nitrogen in particulate materials. Mar Chem 44:217-224

Ólafsson EB, Peterson CH, Ambrose WG Jr (1994) Does recruitment limitation structure populations and communities of macro-invertebrates in marine soft sediments: the relative significance of pre- and post-settlement processes. Oceanogr Mar Biol Annu Rev 32:65-109

Palmer MA (1986) Hydrodynamics and structure: interactive effects on meiofauna dispersal. J Exp Mar Biol Ecol 104: 53-68

Platt MH, Warwick MR (1983) Synopses of the British fauna (N.S.) 28: free-living marine nematodes. Part I: British enoplids. Cambridge University Press, Cambridge

Russel RW, Hunt GLJr, Coyle KO, Cooney RT (1992) Foraging in a fractal environment: spatial patterns in a marine predator-prey system. Landscape Ecol 7:195-209

Schratzberger M, Bolam SG, Whomersley P, Warr K, Rees HL (2004) Development of a meiobenthic nematode community following the intertidal placement of various types of sediment. J Exp Mar Biol Ecol 303:79-96

Schwinghamer P (1981) Characteristic size distributions of integral benthic communities. Can J Fish Aquat Sci 38: 1255-1263

Snelgrove PVR, Butman CA (1994) Animal-sediment relationships revisited: cause versus effect. Oceanogr Mar Biol Annu Rev 32:111-177

Soetaert K, Vincx M, Wittoeck J, Tulkens M, Van Gansbeke D (1994) Spatial patterns of Westerschelde meiobenthos. Estuar Coast Shelf Sci 39:367-388

Soetaert K, Vincx M, Wittoeck J, Tulkens M (1995) Meiobenthic distribution and nematode community structure in five European estuaries. Hydrobiologia 311:185-206

Soetaert K, Muthumbi A, Heip C (2002) Size and shape of ocean margin nematodes: morphological diversity and depth-related patterns. Mar Ecol Prog Ser 242:195-204

Sokal RR, Rohlf FJ (1997) Biometry, 3rd edn. Freeman, New York

Steyaert M, Herman PMJ, Moens T, Widdows J, Vincx M (2001) Tidal migration of nematodes on an estuarine tidal flat (the Molenplaat, Schelde estuary, SW Netherlands). Mar Ecol Prog Ser 224:299-304

Steyaert M, Vanaverbeke J, Vanreusel A, Barranguet C, Lucas M, Vincx M (2003) The importance of fine-scale, vertical profiles in characterizing nematode community structure. Estuar Coast Shelf Sci 58:353-366

Thrush SF (1999) Complex role of predators in structuring soft-sediment macrobenthic communities: implications of changes in spatial scale for experimental studies. Aust J Ecol 24:344-354

Thrush SF, Hewitt JE, Norkko A, Nicholls PE, Funnell GA, Ellis JI (2003) Habitat change in estuaries: predicting broad-scale responses of intertidal macrofauna to sediment mud content. Mar Ecol Prog Ser 263:101-112 
Tita G, Vincx M, Desrosiers G (1999) Size spectra, body width and morphotypes of intertidal nematodes: an ecological interpretation. J Mar Biol Assoc UK 79:1007-1015

Tita G, Desrosiers G, Vincx M, Clément M (2002) Intertidal meiofauna of the St. Lawrence estuary (Quebec, Canada): diversity, biomass and feeding structure of nematode assemblages. J Mar Biol Assoc UK 82:779-791

Underwood AJ, Chapman MG, Connel SD (2000) Observations in ecology: you can't make progress on processes without understanding the patterns. J Exp Mar Biol Ecol 250:97-115

Vincx M, Meire P, Heip C (1990) The distribution of nematode communities in the Southern Bight of the North Sea. Cah Biol Mar 31:107-129

Warwick RM (1971) Nematode associations in the Exe estuary. J Mar Biol Assoc UK 51:439-454

Editorial responsibility: Lisa Levin (Contributing Editor), La Jolla, California, USA
Watzin MC (1983) The effects of meiofauna on settling macrofauna: meiofauna may structure macrofaunal communities. Oecologia 59:163-166

Watzin MC (1985) Interactions among temporary and permanent meiofauna: observations on the feeding and behaviour of selected taxa. Biol Bull (Woods Hole) 169:397-416

Wentworth CK (1992) A scale of grade and class terms for clastic sediments. J Geol 30:377-392

Wieser W (1959) The effect of grain size on the distribution of small invertebrates inhabiting the beaches of Puget sound. Limnol Oceanogr 4:181-194

Willems KA, Vincx M, Claeys D, Vanosmael C, Heip C (1982) Meiobenthos of a sublittoral sandbank in the Southern Bight of the North Sea. J Mar Biol Assoc UK 62:535-548

Wilson WH (1990) Competition and predation in marine softsediment communities. Annu Rev Ecol Syst 21: 221-241

Submitted: March 8, 2005; Accepted: June 22, 2005

Proofs received from author(s): November 3, 2005 